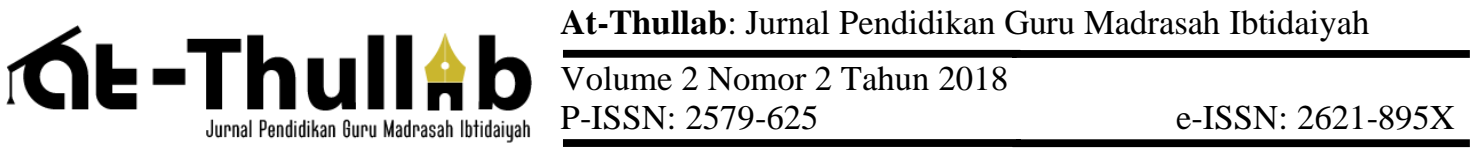

\section{PENDEKATAN CONTEXTUAL TEACHING AND LEARNING (CTL) BERBASIS JAS (JELAJAH ALAM SEKITAR) DALAM PEMBELAJARAN SAINS DI MADRASAH IBTIDAIYAH}

\author{
${ }^{1}$ Ummu Khairiyah, ${ }^{2}$ Roudhotul Ilmiyah, ${ }^{3}$ Afifatus Sa'adah \\ ${ }_{1,2,3}$ Universitas Islam Lamongan \\ e-mail: $\underline{{ }^{1} \text { ummukhairiyah@ unisla.ac.id, }}{ }^{2}$ roudhotulilmiyah4@gmail.com, \\ 3afifatus.s@gmail.com
}

\begin{abstract}
:
The research objective is to describe the activities of students during the learning process that uses the Contextual Teaching and Learning (CTL) approach based on Jelajah Alam Sekitar (JAS) and determine students' responses to learning using the JAS-based CTL approach. Research is a descriptive quantitative research that uses survey methods and literature studies. The learning activities with CTL approach based on the Jelajah Alam Sekitar (JAS) in science or IPA is a group discussion, direct observation, practicum, game, and finall test. Where through these activities in accordance with the principles of the JAS approach which consists of exploration, constructivism, the scientific process, learing community, bioedutainment and authentic assessment. So that the learning process based on Student Centered Learning is no longer Teacher Centered Learning which can make students 'scientific skills honed. Students' responses to learning with the CTL approach based on Jelajah Alam Sekitar (JAS) is $89 \%$ in the good category (interest and very interest).
\end{abstract}

Keywords: Contextual Teaching and Learning (CTL), Jelajah Alam Sekitar (JAS), student response

\section{A. Pendahuluan}

Sains atau IPA pada hakikatnya merupakan ilmu pengetahuan tentang gejala alam yang dituangkan berupa fakta, konsep, prinsip dan hukum yang teruji kebenarannya dan melalui suatu rangkaian kegiatan dalam metode ilmiah. Pendidikan IPA diharapkan dapat membantu peserta didik mempelajari diri sendiri dan alam sekitar, serta menerapkannya di dalam kehidupan sehari-hari. Pendidikan IPA dilaksanakan secara inkuiri dan berbuat sehingga peserta didik dapat memperoleh pemahaman lebih mendalam tentang alam.

Mata pelajaran IPA merupakan mata pelajaran yang dianggap sulit oleh sebagian besar peserta didik dari jenjang sekolah dasar hingga sekolah menengah. Hal tersebut di dukung dengan hasil perolehan ujian akhir sekolah (UAS) yang dilaporkan Depdiknas masih rendah. Permasalahan rendahnya kemampuan sains ini juga dialami oleh siswa VI MI Islam Kedungpring Lamongan terlihat masih banyak kendala yaitu belum 
tercapainya kualitas pembelajaran (kemampuan guru dalam mengelola pembelajaran, kegiatan belajar siswa, respon siswa dalam proses pembelajaran dan terutama hasil belajar siswa) yang maksimal. Penyebab rendahnya kemampuan sains siswa disebabkan oleh aktivitas siswa dalam proses pembelajaran. Aktivitas siswa dalam proses pembelajaran dipengaruhi oleh model pembelajaran yang diterapkan oleh guru.

Kreatifitas guru dalam menerapkan model pembelajaran sangat diperlukan, karena tidak ada model pembelajaran yang paling baik. Penggabungan beberapa model pembelajaran dapat dilakukan dengan memperhatikan kelebihan-kelebihan model pembelajaran yang ada. Model pembelajaran Jelajah Alam sekitar (JAS) salah satu model yang dapat dirujuk dalam pembelajaran khususnya IPA. Jelajah Alam Sekitar merupakan model pembelajaran yang secara komprehensif memadukan pendekatan eksplorasi dan evaluasi di mana mengandung pembelajaran yang menyenangkan (Santika, 2017). Pendekatan JAS memberikan kesempatan kepada peserta didik belajar melalui lingkungan sekitarnya sebagai sumber belajar. Pendekatan JAS memiliki enam komponen sebagai karakteristiknya yaitu eksplorasi, konstruktivis, proses sains, learning community, bioedutaimen, dan asesmen autentik (Alimah, 2016). Kegiatan eksploratif ini memberikan pengalaman nyata kepada peserta didik dan disimulasikan sebagai sumber belajar ilmiah.

Pembelajaran pada mata pelajaran IPA diluar ruangan atau alam sekitar membangun makna atau dapat melibatkan lebih banyak indera yaitu indera penglihatan, pendengaran, peraba, dan penciuman yang memberikan pengalaman lebih berkesan. Oleh karena itu pendekatan JAS memberikan susasana pembelajaran menjadi menarik dan menyenangkan serta peserta didik dapat mengamati secara langsung tentang apa yang sedang dipelajari. Jelajah Alam Sekitar secara komprehensif memadukan berbagai pendekatan antara lain eksplorasi dan investigasi, konstruktivis, keterampilan proses dengan cooperative learning. Menurut Ridlo (2005) ciri kegiatan pembelajaran dengan pendekatan penjelajahan alam sekitar adalah: (1) dikaitkan dengan alam sekitar secara langsung, tidak langsung maupun menggunakan media, (2) ada kegiatan peramalan, pengamatan, dan penjelasan, (3) ada laporan untuk dikomunikasikan baik secara lisan, tulisan, gambar, foto atau audiovisual.

Pendekatan pembelajaran Jelajah Alam Sekitar (JAS) dalam implementasinya menekankan pada pembelajaran yang menyenangkan. Ini merupakan salah satu komponen dari PAIKEM yang mempunyai kepanjangan pembelajaran aktif, inovatif, kreatif, efektif dan menyenangkan, dan berorientasi pada kecakapan hidup (life skill) juga berbasis Contextual Teaching Learning (CTL). CTL merupakan proses pendidikan yang bertujuan menolong peserta didik melihat makna dalam materi akademik yang mereka pelajari dengan cara menghubungkan subyek-subyek akademik dengan konteks 
dalam kehidupan keseharian mereka (Johnson, 2010). Pembelajaran kontekstual juga dikenal dengan experiental learning, real world education, active learning, dan learned centered instruction (Suprijono, 2012).

Komponen-komponen dalam pendekatan CTL antara lain Kontruktivisme, Inquiry, Questioning, learning community, modeling, refleksi, dan asesmen autentik. Wisudawati (2014) menyebutkan bahwa asesmen autentik menekankan proses ilmiah dan performa siswa, dan penilaian dilakukan oleh guru. Adapun tujuan penelitian ini adalah mendeskripsikan aktivitas siswa selama proses pembelajaran yang menggunkan pendekatan CTL berbasis JAS dan mengetahui tanggapan peserta didik terhadap pembelajaran menggunkan pendekatan CTL berbasis JAS.

\section{B. Metode}

Penelitian ini menggunakan metode penelitian deskriptif kuantitatif. Jenis penelitian ini merupakan penelitian deskriptif yang menggunakan metode studi pustaka dan survei. Sampel yang digunakan dalam penelitian ini adalah 31 siswa kelas VI MI Islam Kedungpring. Teknik pengumpulan data melalui observasi kegiatan pembelajaran yang dilakukan dengan pendekan CTL berbasis Jelajah Alam Sekitar (JAS). Kemudian data tersebut dilakukan analisis dengan mendeskripsikan kegiatan pembelajaran yang dihubungkan dengan prinsip pendekatan CTL berbasis JAS . Teknik selanjutnya yakni memberikan lembar kuisioner kepada peserta didik yang terdiri dari 6 indikator dengan 48 butir pertanyaan untuk mengukur tanggapan peserta didik terhadap pembelajaran menggunakan pendekatan CTL berbasis JAS. Data kemudian ditabulasi dan dianalisis menggunakan kriteria:

$204 \leq \mathrm{X} \leq 240=$ sangat baik

$165 \leq \mathrm{X} \leq 203$ = baik

$126 \leq \mathrm{X} \leq 164=$ cukup

$87 \leq \mathrm{X} \leq 125=$ kurang

$48 \leq \mathrm{X} \leq 86=$ buruk

Tabel 1. Indikator pertanyaan kuisioner pendekatan CTL berbasis JAS pada mata pelajaran IPA

\begin{tabular}{ccc}
\hline No & Indikator & Jumlah pertanyaan \\
\hline 1 & Eksplorasi & 6 \\
2 & Konstruktivisme & 6 \\
3 & Proses sains & 10 \\
4 & Learning community & 6 \\
5 & Bioedutainment & 11 \\
\hline
\end{tabular}


$6 \quad$ Asesmen autentik 9

\section{Hasil dan Pembahasan}

Kegiatan pembelajaran yang dilakukan pada mata pelajaran IPA dengan menggunakan pendekatan CTL berbasis JAS ini dilaksanakan selama 1 semester. Peserta didik dibuat dalam kelompok kecil yang terdiri dari 3-4 anggota, melakukan diskusi kelompok sesuai materi setiap pertemuan. Waktu diskusi bervariasi antara 30 sampai 45 menit. Diskusi kelompok dipandu dengan materi yang diberikan guru. Proses diskusi meliputi tahapan pengamatan, pengumpulan data, elaborasi, dan komunikasi. Kegiatan diskusi ini selaras dengan prinsip pendekatan CTL berbasis JAS yaitu eksplorasi, konstruktivisme, proses sains, learing community, bioedutainment dan asesmen autentik. Pembelajaran menggunakan metode diskusi kelompok akan memicu peserta didik untuk mengemukakan pendapatnya sebagai tanggapan atas masalahmasalah yang ada serta merangsang kreativitas berfikir dan aktivitas. Menurut Bahri (2006) kelebihan metode diskusi adalah merangsang peserta didik untuk mengemukakan ide gagasan dan terobosan baru dalam pemecahan masalah.

Kegiatan selanjutnya yakni pengamatan langsung di lingkungan. Melalui pengamatan langsung di lingkungan akan membuat pembelajaran menjadi lebih bermakna. Hal ini karena peserta didik terlibat secara langsung dalam mengaplikasikan teori dan membuat peserta didik tidak jenuh. Selanjutnya yakni kegiatan praktikum, praktikum merupakan cara dalam mengubah pembelajaran yang minds on kedalam pembelajaran hands on (Erwinsyah, 2016). Kegiatan praktikum ini selaras dengan pendekatan JAS yaitu eksplorasi, konstruktivisme, proses sains, learning community, dan asesmen autentik.

Selanjutnya kegiatan game. Kegiatan game dilakukan supaya kegiatan pembelajaran didalam kelas menjadi menyenangkan. Kegiatan game pembelajaran ini selaras dengan prinsip pendekatan JAS yaitu learning community dan bioedutainment. Kegiatan yang terakhir yakni melakukan tes hasil belajar. Kegiatan ini dilakukan untuk mengukur kemampuan kognitif peserta didik. Tes ini selain untuk mengukur kemampuan kognitif peserta didik, juga mengajarkan peserta didik untuk berperilaku jujur dan percaya diri dengan kemampuan sendiri. Kegiatan tes ini selaras dengan pendekatan JAS yaitu asesmen autentik.

Setelah kegiatan pembelajaran berjalan, peserta didik diberikan kuisioner untuk mengetahui tanggapan siswa dengan pelaksanaan pembelajaran menggunakan pendekatan CTL berbasis JAS. Pertanyaan kuisioner memiliki skala $1-5$ dengan kriteria sangat baik, baik, cukup, kurang, dan buruk. Berikut hasil kuisioner peserta didik 
Tabel 2. Tanggapan peserta didik terhadap pembelajaran dengan menggunakan pendekatan CTL berbasis JAS pada mata pelajaran IPA

\begin{tabular}{ccc}
\hline No & Indikator & Rata-rata skor \\
\hline 1 & Eksplorasi & 3,33 \\
2 & Konstruktivisme & 3,67 \\
3 & Proses sains & 4,12 \\
4 & Learning community & 4,11 \\
5 & Bioedutainment & 4,08 \\
6 & Asesmen autentik & 4,13 \\
\hline
\end{tabular}

Berdasarkan data secara keseluruhan, peserta didik memberikan tanggapan yang baik terhadap pelaksanaan pembelajaran dengan presentase sebesar $89 \%$ (baik $63 \%$ dan sangat baik 26\%). Sekitar $11 \%$ responden mengatakan bahwa pelaksanaan pembelajaran dengan pendekatan CTL berbasis JAS adalah cukup baik.

\section{Simpulan}

Berdasarkan hasil penelitian dan pembahasan, maka dapat disimpulkan:

1. Kegiatan pembelajaran dengan pendekatan CTL berbasis JAS pada mata pelajaran Sains atau IPA terdiri atas kegiatan diskusi kelompok, pengamatan langsung, praktikum, game, dan tes tulis. Dimana melalui kegiatan tersebut sesuai dengan prinsip dari pendekatan JAS yg terdiri atas eksplorasi, konstruktivisme, proses sains, learing community, bioedutainment dan asesmen autentik. Sehingga proses pembelajaran berbasis Student Centered Learning bukan lagi Teacher Centered Learning yang dapat membuat kemampuan sains peserta didik terasah.

2. Tanggapan peserta didik terhadap pembelajaran dengan pendekatan CTL berbasis JAS pada mata pelajaran sains atau IPA berada pada kategori baik yaitu 89\% (baik dan sangat baik)

\section{Daftar Rujukan}

Agus, S. (2012). Cooperative Learning Teori dan Aplikasi PAIKEM. Yogyakarta: Pustaka Belajar.

Bahri, Z. (2006). Strategi Belajar Mengajar. Jakarta: PT Asdi Mahasatya.

Erwinsyah. (2016). Relevansi praktikum dan perkuliahan teori pada mata kuliah genetika. 546-553. Proceeding Biology Education Conference.

Johnson. (2010). Contextual Teaching and Learning. Bandung: Kaifa.

Marianti, A. aditya. (2016). Jelajah alam sekitar: pendekatan, strategi, model, dan metode pembelajaran biologi berkarakter untuk konservasi. Semarang: UNNES. 
Ummu Khairiyah, Roudhotul Ilmiyah, Afifatus Sa'adah

Santika, A. manik; D. N. B. C. S. M. Y. (2017). Pendekatan Jelajah Alam Sekitar (JAS) Berbasis Pelestarian Jalak Bali Terhadap Kepedulian Lingkungan Dan Hasil Peta Kognitif Siswa. Jurnal Santiagi Pendidikan, 7(1).

Wisudawati;Sulistyowati, E. (2014). Metodologi Pembelajaran IPA. Jakarta: Bumi Aksara. 